\title{
The benefits of a scientific approach to sustainable development of groundwater in sub-Saharan Africa
}

Jude E. COBBING ${ }^{1}$ \& Jeff DAVIES ${ }^{2}$

${ }^{1}$ CSIR NRE Unit, Pretoria, PO Box 395, 0001, South Africa Tel +27 128413857 Fax +27

128413954 jcobbing@csir.co.za

${ }^{2}$ British Geological Survey, Wallingford, OX10 8BB, UK

\begin{abstract}
With less than ten years to go before the deadline for the Millennium Development Goals (MDGs) falls due, there is an increasing urgency behind the supply of safe drinking water and sanitation facilities to African countries. Although groundwater will form a substantial part of the water used in water supply schemes, particularly in rural areas, the resource is poorly understood in many parts of the continent. Careful and appropriate data collection during project implementation, together with data interpretation and knowledge dissemination can prevent past mistakes being repeated, and reduce the ultimate cost of water supply schemes both from a human and a financial point of view. Hydrogeologists are familiar with this argument, but are not always consulted when water supply schemes are planned. As funding agencies prepare to increase water supply and sanitation implementation in sub-Saharan Africa, it is vital that a scientific approach to groundwater development is more widely adopted, and incorporated at the planning stage of new projects.
\end{abstract}




\section{Introduction}

Improved water supply and sanitation services are recognised as essential to addressing poverty and underdevelopment in Africa. As with other topics in the field of international development, there is no lasting consensus on the best way to proceed in installing or supporting the necessary infrastructure, managing and maintaining it, and replacing it when no longer functional. The debate has moved from models advocating centrally funded, topdown implementation run by national governments, to the more recent emphasis on community funded and managed systems in which non-governmental organisations (NGOs) and the private sector play an important role. Today, partnerships between the government and the private sector ('public-private partnerships'), or between government agencies, NGOs and communities, are frequently discussed. One of the unchanging realities of water-related infrastructure, however, is that the available water resource must be understood and managed prudently if water supply and sanitation schemes are to be sustainable (Robins et al. 2006).

\section{Groundwater and rural water supply}

\section{The new impetus for water supply in Africa}

On the $8^{\text {th }}$ of September 2000, at the largest gathering of heads of state in history, the United Nations General Assembly adopted General Assembly Resolution 55/2, or the 'Millennium Declaration', in which member countries endorsed a series of values and principles designed to advance global development and reduce poverty. Eight Millennium Development Goals (MDGs) were adopted, each with specific targets (Table 1). The Millennium Development Goals have since become a focus for international development activities, with the targets providing a way to measure progress since adoption of the resolution.

The supply of safe drinking water, and the related provision of adequate sanitation, is critical to poverty alleviation and economic growth in the world's poorest countries, and Target 10 of Goal 7 commits the signatories to halving, by 2015, the proportion of people worldwide without access to safe drinking water compared to 1990 levels. At the World Summit on Sustainable Development in Johannesburg in August 2002, the target of halving the proportion of people worldwide without access to sanitation by 2015 (compared with 1990 levels) was added to existing agreements. Whilst the provision of sanitation and clean water is a target in itself, it is integral to the other goals. For example, people (usually women and 
girls) are relieved of the burden of collecting water from distant sources, and can devote more time to economic activities (Goal 1) or education (Goal 2). Lifting this burden contributes to the empowerment of women (Goal 3). Sanitation and clean water are vital in reducing infant mortality and disease (Goals 4 and 6), and improving maternal health (Goal 5) and resistance to diseases such as HIV/AIDS, and these outcomes all promote economic development (Goal 8). Bettering water and sanitation services is one of the cheapest ways of improving people's health (World Bank, 2005). In development terminology, water supply and sanitation is truly a 'cross-cutting' issue.

Table 1 Summary of the Millennium Development Goals (after UNDP 2003)

\begin{tabular}{ll}
\hline Goal & Summary \\
\hline Goal One & Eradicate extreme poverty and hunger. \\
Goal Two & Achieve universal primary education. \\
Goal Three & Promote gender equality and empower women. \\
Goal Four & Reduce child mortality. \\
Goal Five & Improve maternal health. \\
Goal Six & Combat HIVIAIDS, malaria and other diseases. \\
Goal Seven & Ensure environmental sustainability. \\
Goal Eight & Develop a global partnership for development.
\end{tabular}

\section{Providing water: the task for the next ten years}

World progress towards meeting the MDGs, five years after they were adopted, is variable. Whilst some developing regions are on track to reach the safe water supply and sanitation targets, Africa south of the Sahara is lagging behind (World Bank, 2005), and if the current slow rates of improvement in sub-Saharan Africa continue, the region will not even come close to meeting the water supply and sanitation targets. Other indicators are equally dire; for example, rates of child malnutrition in sub-Saharan Africa are rising (World Bank, 2005). The scale of the task facing Africa is daunting. Over the next ten years it is estimated that between 150 and 300 million people will need to gain access to a water supply, and over 200 million to sanitation. If the MDG targets are to be met, a massive improvement in water supply and sanitation coverage is called for. 
Development bodies, national governments and funding institutions are well aware of the improvement that is needed in water supply and sanitation coverage in sub-Saharan Africa, and recent initiatives promise to give a boost to the task of providing clean water and sanitation to all Africans. For example, in April 2005 The African Development Bank (ADB) announced a 'Rural Water Supply and Sanitation Initiative (RWSSI)', in which it pledged to provide an extra half a billion dollars (US) per year for the next 3 years, a sum that almost doubles current funding (Boucher, 2005). The donor community was asked to match the ADB commitment, and indications are that donors are supportive. African countries have been encouraged to scale up their rural water supply and sanitation operations accordingly. Both the Commission for Africa Report (2005) and the EU Water Initiative emphasise the importance of water supply and sanitation in addressing poverty in Africa. Worldwide, there is currently a momentum by donor countries towards increasing aid budgets, in some cases towards $0.7 \%$ of GDP, and this has led to substantial increases in aid in recent years. For example, the annual UK official development assistance, which amounted to more than GBP 4.1 billion in 2004/2005 is set to reach about GBP 6.5 billion by 2006/2007 (House of Commons, 2004). Although much of this money will not be allocated to Africa, some of these increases can be expected to translate to better funding for water-related development initiatives in sub-Saharan Africa.

\section{The role of groundwater}

It is now broadly accepted that if the MDG targets are to be met, groundwater will have a central role to play (see for instance Pietersen, 2005 or MacDonald, et al. 2005). Groundwater is often the most appropriate water source for rural water supply in Africa because it is generally found close to where it is needed, the natural quality is usually good, and it is resistant to even prolonged droughts. In contrast, surface water must be piped from dams or rivers, requires relatively expensive treatment, and can be vulnerable to even short periods of dry weather. In sub-Saharan Africa, more than $80 \%$ of people without access to a safe water supply live in rural areas (WHO/UNICEF, 2007). The funds and expertise to supply all deprived areas of the subcontinent with viable surface water schemes will not be available in the foreseeable future, and this means, quite simply, that if the MDG targets are to be met a large increase in groundwater development will be essential. 
There is a risk inherent in proceeding with large increases in groundwater use without an adequate understanding of the state of the resource (Robins et al., 2003). Questions that need to be answered include:

- How much groundwater is available?

- What is the groundwater quality, and how might this change with time?

- How will abstractions affect the environment?

- Will abstractions be sustainable?

- What is the best way to protect the groundwater from contamination?

Historically, poor data holdings on water resources (both surface water and groundwater) in Africa have compounded the difficulties in developing further resources, and this has been recognised as an important regional issue by the World Water Council and others (World Water Forum, 2000).

Current aid policies increasingly favour the direct transfer of money to African governments ('budget support'), and funding for rural water supply and sanitation schemes is often dependent on the recipient government having an acceptable water policy in its Poverty Reduction Strategy Paper (PRSP). Thus, an incentive exists for governments to include water supply strategies in PRSPs and obtain funding although the capacity to implement and monitor the schemes may still be lacking. Whilst the benefits of this type of direct funding by donors are many, there is a possible risk of groundwater projects being implemented without sufficient regard for and a scientific understanding of the groundwater resource. Treatment of water and sanitation in PRSPs is generally neither comprehensive nor consistent (SDTF, 2003; ODI, 2004).

Groundwater is often called a 'hidden resource' because it cannot be seen in the same way as water in a river, lake or reservoir. The volumes of groundwater are large, however - it is estimated that there is about one hundred times more fresh groundwater on earth than all the fresh water in rivers and lakes (Shiklomanov, 1998). The management of groundwater has frequently been overlooked in Africa for a number of reasons.

The lack of capacity for the centralised or organised collection, storing and dissemination of groundwater data in many African countries. Economic 'Structural Adjustment' policies applied in many African countries since the early 1980s led to a decline in public sector funding and consequent shrinking of public sector ability. The centralised coordination of 
groundwater development was eroded, and not always replaced adequately by private sector alternatives. Viable institutions underpin national policy and legal frameworks necessary for efficient service expansion (Carter, et al., 1993).

The lack of skilled staff. In many countries, expatriate hydrogeologists working in the postindependence years were not always succeeded by skilled local replacements; it can also be difficult to retain skilled personnel working on rural water supply issues. HIV/AIDS has worsened staff shortages in recent years (Ashton \& Ramasar, 2002).

The fact that there are relatively few high yielding regional aquifers that can be monitored or tested in a conventional way. Much of Africa is underlain by low-yielding basement type aquifers, which cannot be assessed in the same way as regional aquifers (Clark, 1985).

The small quantities abstracted for community supply are often believed to be inherently sustainable (both from a quality and a quantity point of view). This is in part due to a perception which arose in the 1980s 'water decade' that groundwater suitable for small water supplies was ubiquitous across most of Africa, and that the challenges were primarily technical and logistical such as mobilisation, drilling, and operation and maintenance. This misconception persists in some quarters today, even where higher yielding groundwater sources are considered.

Essentially, there is a danger that groundwater development for basic rural needs will be seen only in terms of the engineering problems: e.g. drilling, pump installation, maintenance and the like, together with the software aspects of community participation, management and ownership. Rural water supply will be a matter of 'tanks and taps', rather than the prudent use of a sometimes-complex resource. This approach neglects understanding the resource base on which water supply depends, and thus minimises the importance of data collection during installation as well as some form of monitoring after the scheme is in place. In comparison to the importance given to monitoring and regulating surface water resources, and the expense of surface water treatment, it is surprising that groundwater is often assumed to need little or no assessment or monitoring.

Finally, without accurate data, it is difficult to assess the success of groundwater supply schemes beyond simple 'wet or dry' criteria. This approach ignores the nature of the resource (geology, recharge, etc.), so that when comparing the relative success of water schemes we may be comparing apples with pears. One scheme might be in a good alluvial environment, where success rates of more than $98 \%$ and very good water quality might be expected, whilst 
another scheme might be in a hydrogeologically difficult area where success rates of 50 or $60 \%$ and water of adequate quality would be considered exceptional. This leads to the danger of implementing agencies steering clear of difficult areas for fear of affecting their statistics, and concentrating on areas where they know wet boreholes are easy to site. This has happened on the Afram Plains in Ghana (see later), and conversations with hydrogeological technicians in Nigeria in 2005 confirm that this is also happening there, to the obvious detriment of those unfortunate communities who happen to live in areas underlain by (for example) soft mudstones (MacDonald et al., 2005).

Apart from the huge increase in groundwater development that is necessary to meet the MDGs, additional demands will be made on groundwater in many areas in the coming years. For example, many rural people in South Africa consider a water supply from a handpump an adequate facility only, and aspire to a water supply from a tap, preferably inside their household. In addition, many regard on-site or 'dry' sanitation as backward, and desire a water-borne waste removal system (Harvey \& Reed, 2004). Both piped water supplies and waterborne sewage systems require water resources larger than required by a handpump system. As economic growth takes place, it is inevitable that greater demands will be placed on groundwater resources.

Today, some $41 \%$ of arable land in southeast Asia is irrigated, compared with less than $4 \%$ in Africa (NEPAD, 2003). The 'green revolution' in south Asia was partly brought about by a large increase in the area of irrigated land. Niaz (1985) estimated that the World Bank had loaned about 1.4 billion US dollars up until 1983 for the purposes of groundwater development, much of it for agriculture, and that this assistance was provided mainly to Asia. Some experts see a substantial increase in irrigation as a fundamental requirement for Africa to become sufficient in food, for rural growth, and for rural livelihoods to be sustained (NEPAD, 2003; Commission for Africa, 2005). However, whilst much of the irrigated land area in Asia is underlain by very productive regional aquifers (for example the alluvial aquifer systems of the Gangetic plain), much of Africa's irrigable land is underlain by lower-yielding basement aquifers. Boreholes in the alluvial aquifers of Asia frequently yield 40 or $50 \mathrm{l} / \mathrm{s}$, but successful boreholes in many African environments yield less than $10 \%$, or more often $1 \%$, of that (MacDonald et al., 2005). Groundwater resources in large areas of Africa will need to be carefully assessed and managed if even a modest increase in irrigation by groundwater is to be sustainable. High yielding aquifers do exist in places in sub-Saharan Africa (for example the Witwatersrand Dolomites of South Africa or the coastal alluvial aquifers of Mozambique), 
but it is likely that innovative solutions will be required, and new approaches tried in pilot projects, to exploit groundwater effectively for irrigation purposes in many countries.

\section{Case Studies}

Two case studies have been selected illustrating the value gained by adopting a scientific approach to finding, developing and managing groundwater. Both examples are drawn from Africa, but the principles could equally be applied to any developing region in which groundwater is important.

\section{Afram Plains, Ghana}

The Afram Plains area is located in the Eastern Region of Ghana (Figure 1), in the Volta River basin, and receives variable rainfall during a six-month wet season. Although the average annual rainfall is high (around $1200 \mathrm{~mm} / \mathrm{a}$ ), during the dry season water is scarce surface water sources such as ponds that form along the courses of the ephemeral drainage system soon dry up, and springs are rare. Reliance on unprotected pools and dugouts for water supply in the dry season results in diarrhoeal disease, and much time and effort in water collection. The area is also one of the few remaining in Africa where guinea worm infections in humans are still found. The Afram Plains is underlain by rocks of the Voltaian Sedimentary Basin, deposited unconformably upon older Precambrian rocks (Shackleton, 1976; Black \& Liegeois 1993). These rocks have minimal primary permeability and porosity, and groundwater storage and movement is consequently via fractures, bedding planes and other discontinuities. Groundwater exploration is regarded as particularly difficult due to the low primary permeabilities and the variable geology, and serious problems are experienced by water development agencies active in the area.

Development of the area's groundwater resources began in 1963 when the Geological Survey of Ghana and the Volta River Authority (VRA) drilled several boreholes to serve populations displaced by the rising waters of Lake Volta following the completion of the Akosombo Dam on the Volta River. Since that time, the population has grown considerably, and census data show a $250 \%$ increase in the farming population between 1970 and 1984, attracted by fertile soils and improving infrastructure. There are now more than 140 villages on the Afram Plains. 
Table 2 Summary of available information on borehole drilling success on the Afram Plains, 1963 to 2001 (after Cobbing \& Davies (2004)

\begin{tabular}{lllll}
\hline Organisation & Period & $\begin{array}{l}\text { Total } \\
\text { boreholes }\end{array}$ & $\begin{array}{l}\text { Successful } \\
\text { boreholes }\end{array}$ & $\begin{array}{l}\text { Unsuccessful } \\
\text { boreholes }\end{array}$ \\
\hline Volta River Authority & $1963-1965$ & 10 & 6 & 4 \\
Catholic Church group & 1984 & 47 & 28 & 19 \\
$\begin{array}{l}\text { World Vision } \\
\text { International }\end{array}$ & $1990-1995$ & 152 & 92 & 60 \\
$\begin{array}{l}\text { WaterAid/Afram Plains } \\
\text { Dev. Org. }\end{array}$ & $1996-2001$ & 101 & 67 & 34 \\
$\begin{array}{l}\text { DANIDA exploration } \\
\text { boreholes }\end{array}$ & 2001 & 5 & & 0 \\
Total & & $\mathbf{3 1 5}$ & $\mathbf{1 9 8}$ (63\%) & $\mathbf{1 1 7}$ (37\%) \\
\hline
\end{tabular}

Table 2 shows the substantial numbers of dry boreholes drilled in this area. In addition, some boreholes which were initially classed as successful have failed after two to three years of use. This is highly significant, as communities come to rely on their groundwater sources, and populations attracted to the area by the groundwater supply have no effective alternative water source if boreholes fail. Generally, boreholes are classed as successful if, in the opinion of the driller or site supervisor, they will support a handpump. 


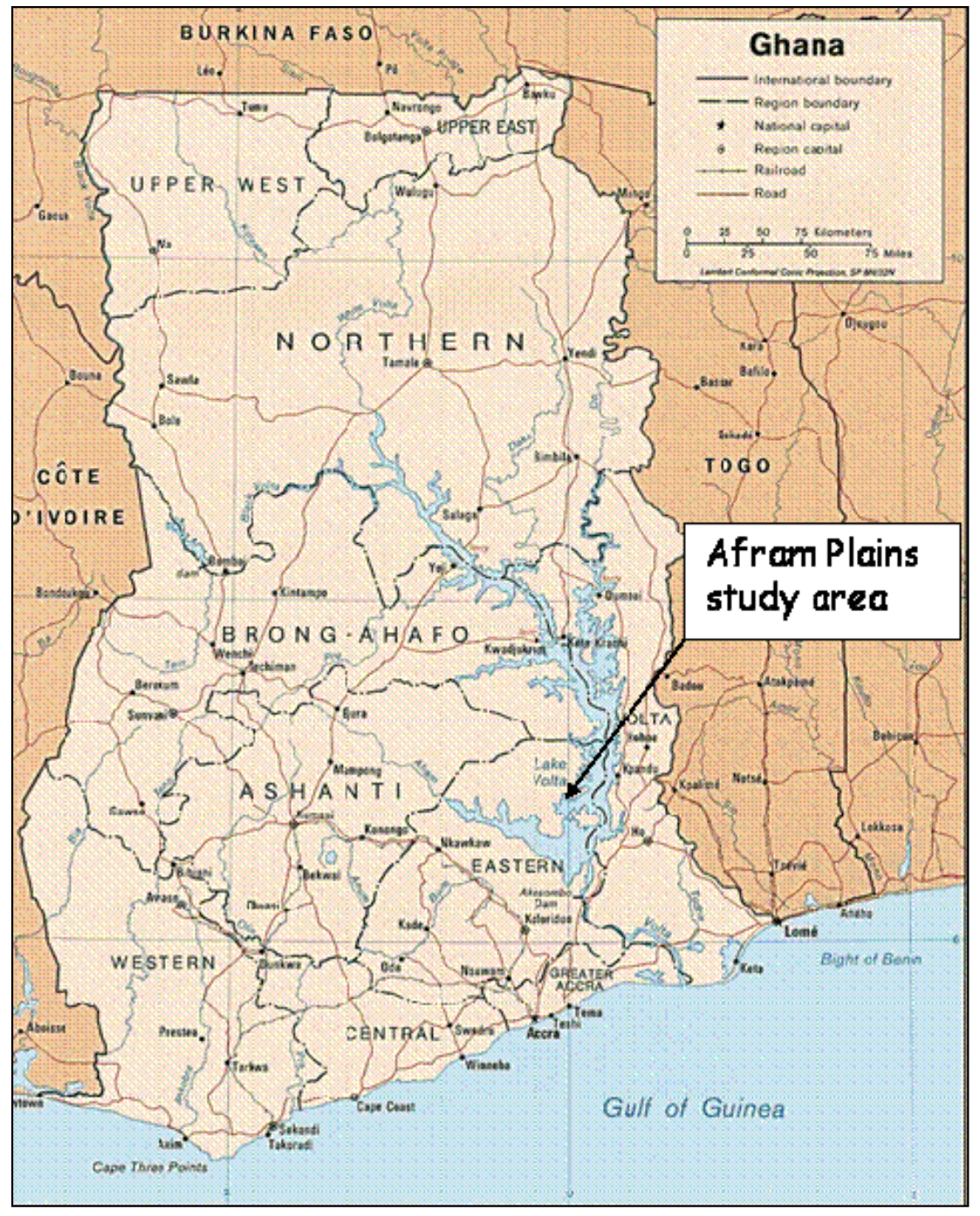

Figure 1 Map of Ghana showing the Afram Plains study area (map source CIA 2006)

A British Department of International Development (DfID) funded study by the British Geological Survey working together with WaterAid, the Danish aid agency DANIDA, and the Afram Plains Development (Davies \& Cobbing, 2002; Cobbing \& Davies, 2004) collected the following data during a programme of drilling in the area: EM-34 surface geophysics was carried out at the sites of new boreholes; borehole chip-samples were logged and photographed; drilling penetration rates, water strikes, blow yields, final water-levels and total borehole depths were recorded; borehole construction details were recorded; basic water 
quality measurements were made on site, and water samples taken for geochemical analysis; and boreholes were geophysically logged (conductivity, temperature, natural gamma, resistivity, and point resistance).

Based on these and other data, guidelines for groundwater exploration for the Afram Plains were subsequently compiled, and a basic groundwater exploration map was constructed to assist future groundwater development (see Figure 2 and Table 3). Initial use of these resources has been encouraging - for example, the five deep exploration boreholes sited towards the end of the project were successful, and one of the outcomes of the work has been a realisation that deeper ( $>100 \mathrm{~m}$ ) boreholes may well have yields $>2 \mathrm{l} / \mathrm{s}$, possibly because they intercept fractures which are recharged by the lake. It is very likely that the careful use of this information will increase borehole success rate in the area. Prior to this project, the drilling success rate had not improved significantly over more than 30 years of groundwater exploration efforts. This is partly because data from each drilling project were either not collected and interpreted, or were not readily available to future workers. In effect, lessons were not learned from one project to the next, resulting in mistakes being repeated.

A typical example of the difficulties of sharing groundwater data was observed in Ghana. The drilling contractor employed a geophysical team to site the village water supply boreholes that were drilled on the Afram Plains in 2001. The team used conductivity (EM-34) and resistivity methods, and also took topography and vegetation into account. At least two sites were identified at each village in the event of the first site being dry, and this produced a lot of data. Large amounts of similar data are held by the geophysicist, gained from a variety of other projects in West Africa. It was suggested that these data could be used by other projects in the Afram Plains and in similar areas, and could also form the basis of a valuable paper or report since it reflected considerable local knowledge and experience gained over many years. The geophysicist responded by stressing that the data had value not only to him but also to others working in the groundwater field. Since he was only paid for the time that he actually spent working, making his data more accessible could lead to a reduction in contracts and therefore income for him. He gave the example of a previous contract that required him to locate three potential sites for each of a series of boreholes. Many of the sites remained "unused". Some years later his data were used by another geophysical contractor to site more boreholes in the area for little extra cost or effort.

In other words the geophysicist perceived that making his data widely available helped his competition and thus harmed his interests. There was also a lack of access to equipment, such 
as GPS receivers, copiers and laptop computers, to record and compile field data. Data often remained in a rough form as they were recorded in the field (and as a single copy), since analysis was often performed in the field and the results not formally recorded with an outside audience or agency in mind. A great amount of potentially valuable data have been lost in this way. It is clear that incentives may be needed in many parts of Africa if private contractors are to make 'their' data accessible, or alternatively the handover of data needs to be specified in contracts.

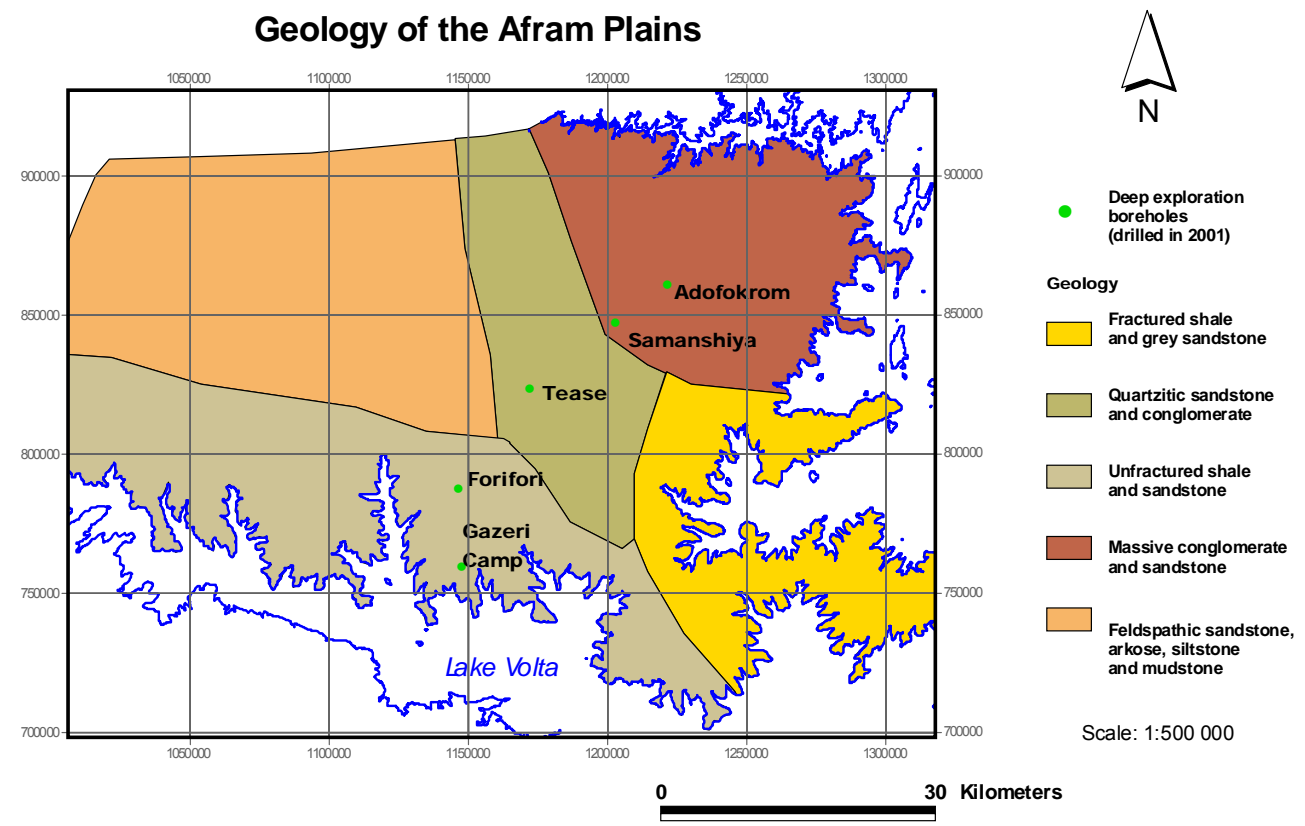

Figure 2 Map of the Afram Plains showing simplified hydrogeological units (compiled using a variety of sources reported in Cobbing \& Davies (2004)

Table 3 Summary of notes on groundwater potential accompanying the map

\begin{tabular}{lll}
\hline Geological & Summary of & Notes on groundwater occurrence \\
area (see & groundwater & \\
Figure 2) & potential & \\
\hline Massive & Moderate & Weathered conglomerate gravel often visible at surface. Good recharge, best
\end{tabular}




\begin{tabular}{|c|c|c|}
\hline $\begin{array}{l}\text { conglomerate and } \\
\text { sandstone }\end{array}$ & & $\begin{array}{l}\text { borehole sites located in valleys. Boreholes should be drilled to below present } \\
\text { day lake level for best yields, since flow may be induced from the lake along } \\
\text { fracture zones. Problems with pollution in villages, otherwise groundwater } \\
\text { quality good. Success rate } \sim 66 \% ; 38 \% \geq 30 \mathrm{l} / \mathrm{min}\end{array}$ \\
\hline $\begin{array}{l}\text { Fractured shale and } \\
\text { grey sandstone }\end{array}$ & Low to very low & $\begin{array}{l}\text { Low altitude lakeside areas. Little information has been recorded in this area; it } \\
\text { is possible that few boreholes have been attempted. Groundwater quality } \\
\text { thought to be poor to saline. Rainwater harvesting may be necessary in some } \\
\text { villages. }\end{array}$ \\
\hline $\begin{array}{l}\text { Quartzitic } \\
\text { sandstone and } \\
\text { conglomerate }\end{array}$ & Moderate & $\begin{array}{l}\text { Quartzitic sands often visible at surface. Moderate recharge, best sites located } \\
\text { in valleys. Boreholes should be drilled to below present day lake level. May be } \\
\text { able to induce flow from the lake along fracture zones. Problems with pollution } \\
\text { in villages, otherwise groundwater quality good. Success rate } \sim 67 \% ; 40 \% \geq 30 \\
\mathrm{l} / \mathrm{min}\end{array}$ \\
\hline $\begin{array}{l}\text { Feldspathic } \\
\text { sandstone, arkose, } \\
\text { siltstone and } \\
\text { mudstone }\end{array}$ & Low to moderate & $\begin{array}{l}\text { Weathered purple brown sandstone platform surface beneath thin ferricrete. } \\
\text { Very poor recharge potential due to re-cemented layer down to } \sim 60 \mathrm{~m} \text {. Deep } \\
\text { holes may intercept weathered zones. Direct recharge from lake along fractures } \\
\text { unlikely. Fractures poorly defined. Groundwater quality good. Success rate } \\
\sim 66 \% ; .39 \% \geq 30 \mathrm{l} / \mathrm{min} \text {, however boreholes known to fail after two or three } \\
\text { years of use. May need to consider artificial recharge of boreholes. }\end{array}$ \\
\hline $\begin{array}{l}\text { Unfractured shale } \\
\text { and sandstone }\end{array}$ & Low & $\begin{array}{l}\text { Poor to moderate recharge to tight formation except where conglomeratic } \\
\text { bands are present. Boreholes should be drilled to below present day lake level. } \\
\text { Groundwater quality may be poor to saline. Success rate } \sim 50 \% \text {;t. } 14 \% \geq 30 \\
\text { I/min. }\end{array}$ \\
\hline
\end{tabular}

The Afram Plains is perhaps an extreme case, in that the hydrogeology is particularly difficult (i.e. successful boreholes are difficult to site, water quality is sometimes poor, and some boreholes fail after a few years due to inadequate recharge), there is an acute lack of skilled staff and other resources in this remote area, and institutions in Ghana responsible for the collection and assessment of drilling data lack funding and capacity.

\section{North central Tanzania}

The Tabora, Singida and Manyara regions of Tanzania (Figure 3) are amongst the most deprived in sub-Saharan Africa in terms of water supply and sanitation coverage, and substantial efforts have been made over the past few years to improve the water supply situation. The occurrence of groundwater within the Tabora, Singida and Arusha (including Manyara) regions is described in Regional Water Master Development Plans produced during the 1980s and 1990s (Arusha Regional Water Master Plan, 2000). Since the compilation of 
the Regional Water Development Plans, rural groundwater development has proceeded primarily as a partnership between the Ministry of Water, its former nominally privatised component parts (such as the Drilling and Dam Construction Agency (DDCA) and international NGOs such as WaterAid and World Vision. The UK has provided scientific advice over a number of years on the sustainable development of the groundwater resources of the area in cooperation with these partners (e.g. Smedley et al., 2002; Davies \& Ó Dochartaigh 2002; Davies, 2005).

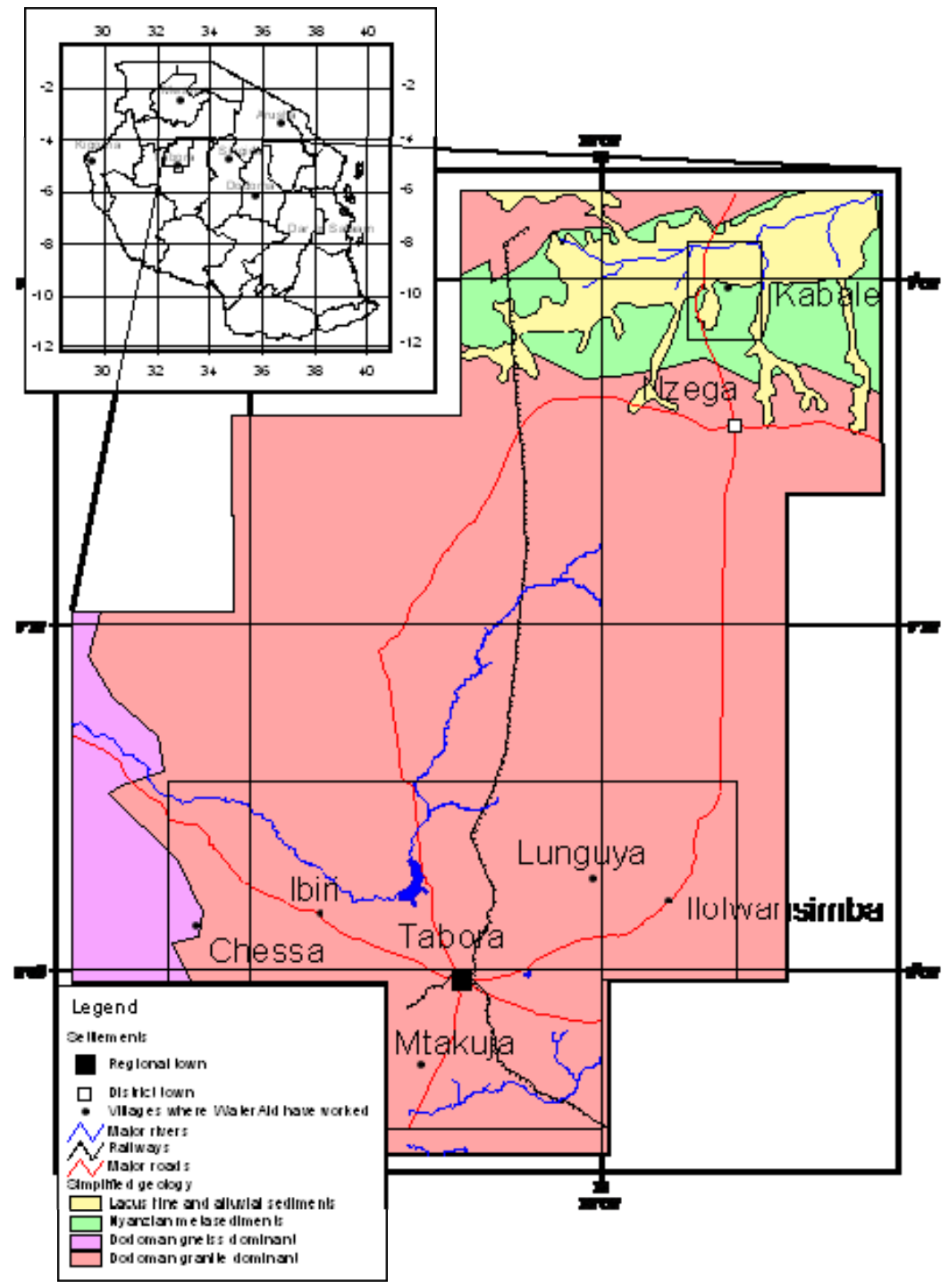




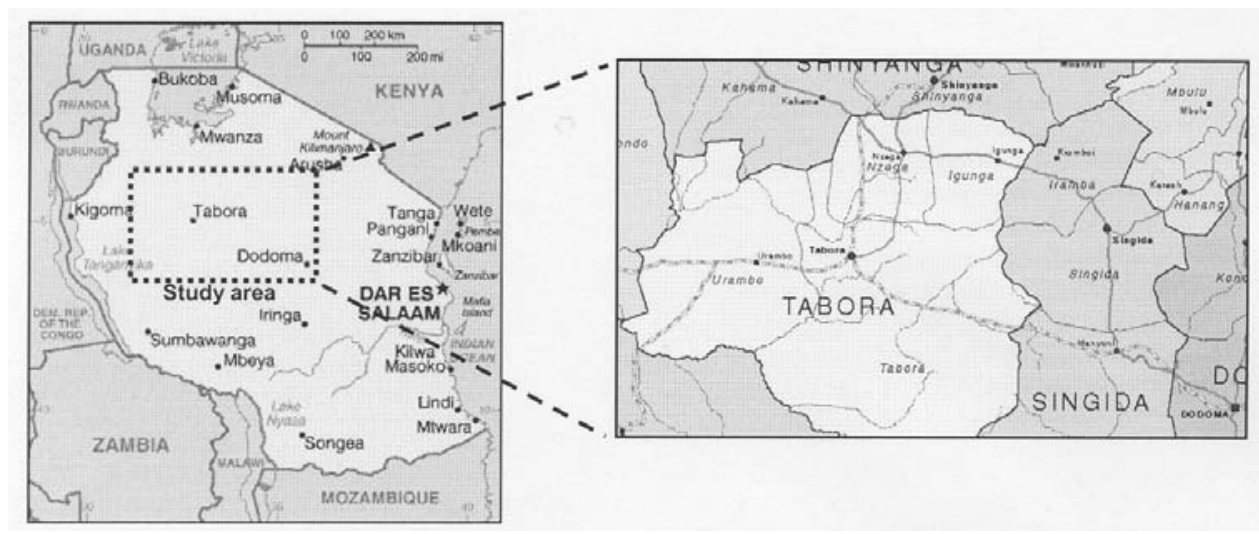

Figure 3 Map of Tanzania showing the general study area. After: CIA, 2006 (country map) and Davies, 2005 (detail map)

The area is underlain by granitic and metasedimentary basement rocks of the Archean Granite Shield. Sandy soils occur with ferricretes on hillsides and heavy "Mbuga" clays (black vertisol soils) in valleys. Cenozoic and later lacustrine and alluvial deposits are found in some areas (Davies, 2005). Recognised technical problems in these areas include:

1. water quality problems, including the widespread occurrence of high fluoride concentrations in groundwater;

2. difficulties with the location of wells and boreholes capable of yielding sustainable quantities of water sufficient to meet community water supply needs.

These problems are exacerbated by problems common to many developing areas, including a lack of trained personnel, a lack of good quality groundwater data, and limited resources with which to carry out groundwater development work. An increasing population and better water infrastructure is placing growing demands on already limited groundwater resources, which in some cases are unable to deliver water of the desirable quantity and quality. However, a scientific approach to the difficulties of developing groundwater resources has helped to identify the following important points, which have proved valuable in on-going projects.

- The development of databases by using GPS equipment to locate boreholes and other water sources (including the locations of dry boreholes) on topographic and geological maps has proved to be extremely useful in planning and costing future projects, and arriving at a realistic assessment of the water resources of an area.

- Experienced ex-government hydrogeologists are employed by WaterAid to supervise and acquire geological and hydrogeological data during borehole drilling and testing, data 
which have proved to be of considerable benefit in planning future projects, and in the monitoring of existing boreholes.

- Data on the groundwater resources, gathered both during implementation and in follow-up monitoring phases, have proved that in some areas the water supply needs of rural communities cannot be met by groundwater alone, and that other solutions (such as conjunctive use of groundwater and rainwater harvesting) are needed. The data which underpin the groundwater development makes this less of a 'guessing game'.

- In some areas, hand-dug-wells are feasible. These avoid high drilling costs whilst at the same time allowing a much greater degree of community participation. However, in other areas traditional methods of accessing groundwater are not adequate. The choice of technology is frequently determined by hydrogeological conditions (e.g. knowledge of water table fluctuations or quality changes with depth) and scientific advice allows planners to make a much more realistic assessment of what is possible.

Data collected during recent BGS/WaterAid project work (Davies \& Ó Dochartaigh, 2002; Smedley, et al., 2000) and the collation of available existing data, provide a framework for the development of groundwater resources in the region (Davies, 2005). The hydrogeological characteristics of the various low permeability rock types that underlie the Tabora Region are complex. Groundwater potential depends on many factors, including geology, structure (particularly fracture patterns), geomorphology, and past climates. The different geological units have different hydrogeological characteristics, but all are low yielding. Groundwater occurs in zones of weathering and in discrete fracture zones within bedrock. Shallower aquifer units, often on hillslopes, contain young, recently recharged water, which flows rapidly downslope to discharge in valleys. This rapid movement of water can also lead to rapid transport of contaminants in shallow zones, which is seen in the high levels of nitrate in some of the shallow wells tested. Older, more mineralised water is often present in fracture zones. In Nyanzian rocks, water bearing fracture zones are often buried too deep beneath Mesozoic and Quaternary sediments to be determined using geophysical survey methods. Water from most of the boreholes and hand-dug-wells tested had high levels of iron, aluminium, fluoride and/or barium, all of which associated with health problems.

Data from this project and other work have been interpreted to provide, amongst other things, a summary diagram of the hydrogeological potential of the Nzega and Tabora areas, together with a table describing the groundwater characteristics and potential of each unit (see Figure 4 
and Table 4). These resources were designed to be laminated as a single A4 sheet for use in the field by technicians and others.

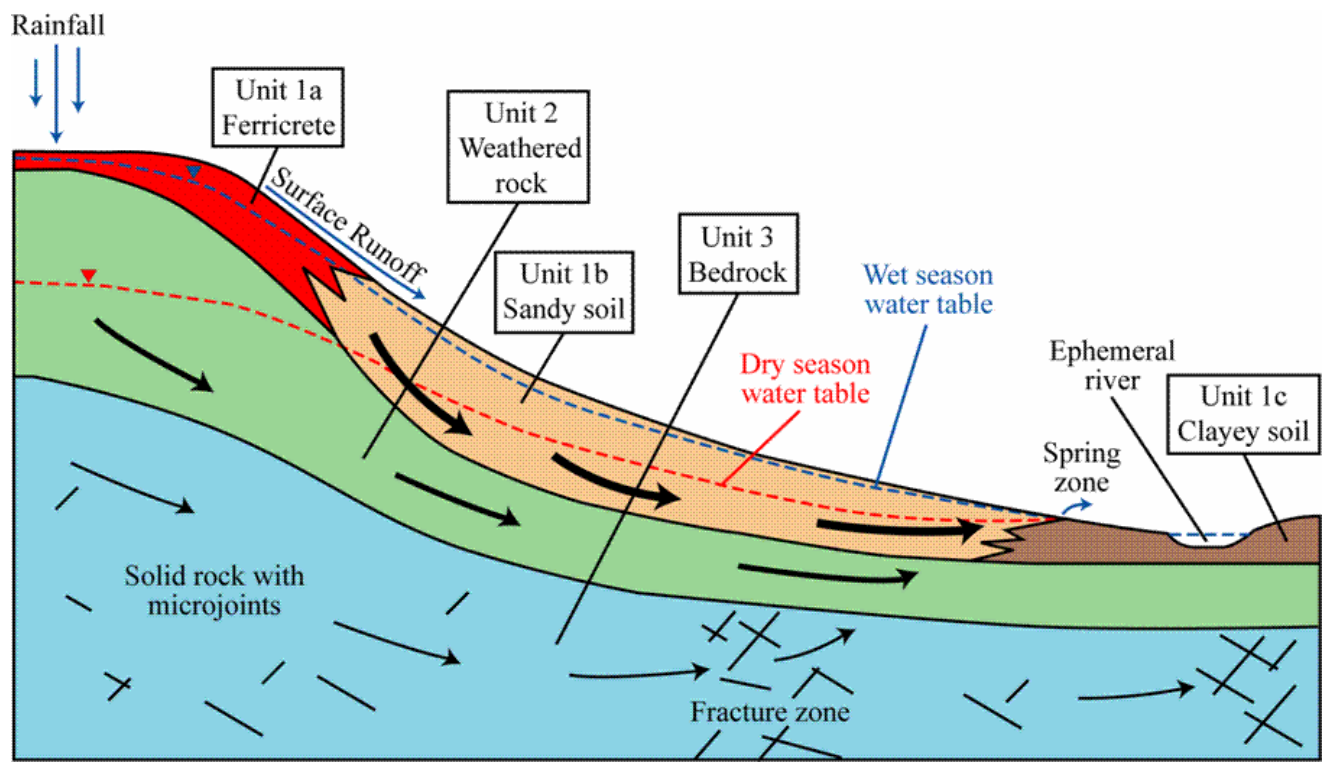

Figure 4 Simplified diagram of groundwater occurrence in the Nzega and Tabora areas, Tanzania (Davies, 2005)

In addition to the single-sheet summary provided above, a list of key issues for the development of groundwater in north-central Tanzania was compiled:

The Importance of Accurate Site Recording and Location: Both wet and dry boreholes are a valuable source of data. In the past, water supply development programmes have failed to locate boreholes and other survey sites accurately, or have relied on sometimes-ambiguous place names. Inexpensive GPS systems now provide a simple means of accurately locating boreholes, villages, rivers, roads and other data points.

Use of Geophysical Surveys for Borehole Siting: Electrical resistivity surveys are used to determine the apparent thickness of the weathered zone. Borehole sites are then located where this zone appears to be thickest. Geophysical surveys need to be undertaken in conjunction with the interpretation of aerial photography (used to locate linear target structures such as 
fault zones) with sites located on a 1:50 000 topographic map using a GPS if the optimum amount of information is to be obtained from the correlation of drilling data and geophysical survey results. EM34 equipment can be used for the rapid determination of lineament locations. Ideally target lineations should be located using conductivity (EM-34) traversing; and electrical resistivity used to investigate depths of weathering on the fault zone.

Table 4 Summary of the groundwater potential of the units identified in Fig. 3 for the Nzega and Tabora areas, Tanzania (after Davies, 2005)

\begin{tabular}{|c|c|c|c|}
\hline Hydrogeological unit & $\begin{array}{l}\text { Groundwater } \\
\text { potential }\end{array}$ & $\begin{array}{l}\text { Groundwater } \\
\text { Quality }\end{array}$ & $\begin{array}{l}\text { Notes on groundwater } \\
\text { occurrence }\end{array}$ \\
\hline $\begin{array}{l}\text { Unit 1a: Upper slope soils - } \\
\text { Nodular, hard, red-brown } \\
\text { ferricrete with white clay at base. } \\
2-10 \text { m thick. }\end{array}$ & Moderate & $\begin{array}{l}\text { Low } \mathrm{pH}(4.5-5.5) ; \text { SEC } \\
<200 \mu \mathrm{S} / \mathrm{cm} \text {; may be } \\
\text { high iron. Risk of } \\
\text { nitrate and e-coli } \\
\text { pollution. }\end{array}$ & $\begin{array}{l}\text { Ferricrete seen at surface and exposed in } \\
\text { wells. Moderate-high storage, short } \\
\text { groundwater residence time: high yield in } \\
\text { wet season when ferricrete is saturated } \\
\text { and first weeks/months of dry season; } \\
\text { low/no yield available for remainder of dry } \\
\text { season. Wells } 10-15 \mathrm{~m} \text { deep. }\end{array}$ \\
\hline $\begin{array}{l}\text { Unit } 1 \mathrm{~b} \text { : Lower slope soils - Light } \\
\text { brown sands with interbedded } \\
\text { clay and clay at base. } 2-10 \mathrm{~m} \\
\text { thick. }\end{array}$ & Moderate & $\begin{array}{l}\text { Neutral pH and low } \\
\text { SEC. May be clay in } \\
\text { suspension and/or high } \\
\text { fluoride. }\end{array}$ & $\begin{array}{l}\text { Sands seen at surface and in wells, } \\
\text { investigate with hand auger. Unlined wells } \\
\text { prone to collapse. Saturated sands have } \\
\text { moderate storage and residence times: } \\
\text { moderate yield; low yield at end of dry } \\
\text { season; low/no yield after long droughts. } \\
\text { Spring zones at junction with valley } \\
\text { bottom clays. Wells } 10-15 \text { m deep or } \\
\text { spring boxes. }\end{array}$ \\
\hline $\begin{array}{l}\text { Unit 1c: Valley bottom soils dark } \\
\text { grey, cracking mbuga clays with } \\
\text { thin sands and calcrete nodules; } \\
\text { gravels at base. } 2 \text { - } 10 \text { m thick. }\end{array}$ & Low & May be brackish. & $\begin{array}{l}\text { Gravel seen in wells, or investigate with } \\
\text { hand auger. Gravels beneath surface } \\
\text { clays have low storage, very slow } \\
\text { groundwater throughflow: low/no yield. } \\
\text { Wells } 10-15 \mathrm{~m} \text { deep. }\end{array}$ \\
\hline $\begin{array}{l}\text { Unit } 2 \text { (Nzega): Weathered } \\
\text { Nyanzian meta-sediments and } \\
\text { ash. Silvery-grey, red-brown or } \\
\text { brown; moderately hard to very } \\
\text { soft. } 2 \text { - } 30 \mathrm{~m} \text { thick. }\end{array}$ & Low to moderate & $\begin{array}{l}\text { TDS and SEC increase } \\
\text { with depth }\end{array}$ & $\begin{array}{l}\text { Upper weathered zone and weathered } \\
\text { fracture zones. Low groundwater storage, } \\
\text { very long residence times: low yields } \\
\text { available year-round. Wells } 10-15 \mathrm{~m} \\
\text { deep, boreholes < } 60 \mathrm{~m} \text { deep. }\end{array}$ \\
\hline
\end{tabular}




\begin{tabular}{|c|c|c|c|}
\hline $\begin{array}{l}\text { Unit } 3 \text { (Nzega): Unweathered hard } \\
\text { grey, red or brown Nyanzian } \\
\text { metasediments, some hard black } \\
\text { ash, fractures near top, quartz or } \\
\text { calcite veins, >50 m thick. }\end{array}$ & Low to high & $\begin{array}{l}\text { TDS and SEC } \\
\text { decrease with depth }\end{array}$ & $\begin{array}{l}\text { Fractures near top have low-moderate } \\
\text { groundwater storage and short residence } \\
\text { times: high yields for short periods } \\
\text { following borehole construction. Main rock } \\
\text { body has low storage \& very long } \\
\text { residence times in microjoints: very low or } \\
\text { no yield. Boreholes }<60 \mathrm{~m} \text { deep. }\end{array}$ \\
\hline $\begin{array}{l}\text { Unit } 2 \text { (Tabora): Weathered } \\
\text { brown, grey and red-brown } \\
\text { Dodoman igneous and } \\
\text { metamorphic rocks, medium to } \\
\text { coarse grained, hard to very soft. } \\
2-20 \text { m thick. }\end{array}$ & Low to moderate & $\begin{array}{l}\text { TDS and SEC increase } \\
\text { with depth, may } \\
\text { contain white } \\
\text { suspended clays } \\
\text { and/or high iron. }\end{array}$ & $\begin{array}{l}\text { Upper weathered fracture zones, } \\
\text { especially pegmatites. Low groundwater } \\
\text { storage, very long residence times: low } \\
\text { yields available year-round. Wells } 10-15 \\
\text { m deep, boreholes < } 60 \text { m deep. }\end{array}$ \\
\hline $\begin{array}{l}\text { Unit } 3 \text { (Tabora): Unweathered } \\
\text { hard white, black, pink, dark green } \\
\text { or black Dodoman igneous and } \\
\text { metamorphic rocks, fine to coarse } \\
\text { grained, fractures near top > } 50 \mathrm{~m} \\
\text { thick. }\end{array}$ & Low to high & $\begin{array}{l}\text { TDS and SEC } \\
\text { decrease with depth }\end{array}$ & $\begin{array}{l}\text { Fractures near top have low-moderate } \\
\text { groundwater storage and short residence } \\
\text { times: high yields for short periods } \\
\text { following borehole construction. Main rock } \\
\text { body has low storage and very long } \\
\text { residence times in microjoints: low or no } \\
\text { yield. Boreholes }<60 \mathrm{~m} \text {. }\end{array}$ \\
\hline
\end{tabular}

Data Gathered During Borehole Drilling: At little added expense, much useful geological and hydrogeological data can be gathered during the drilling of a borehole, including detailed geological descriptions, penetration rates, and flow rates. These data can be used to make a more objective assessment of the borehole potential, so that low yielding boreholes can be abandoned, and higher yielding boreholes identified and perhaps targeted for further development. Photographs have been used to record rock colour changes with depth that can be correlated with patterns of weathering, fracturing and water struck zones.

Test Pumping: A bail test (a modification of a slug test) demonstrated during the field study in Tabora provided field personnel with a rapid procedure to assess the yield potential of a borehole, without undertaking a standard pumping test (see MacDonald et al., 2005). Simple procedures were provided to help interpret these tests. However, in some fractured aquifers interpretation can be more difficult, especially if the tests are carried out over short time periods (e.g. less than 5 hours). Fractured aquifer systems can initially give high yields, but if pumping continues they can be dewatered and may suddenly fail. If this behaviour is common in a project area, a longer-term pumping test should be carried out to allow a more accurate assessment of borehole potential. 
Hydrochemical Sampling: Hydrochemical sampling and analysis is used to establish inorganic groundwater quality, and provide information about recharge and contamination. The routine measurement of borehole water specific electrical conductance (SEC) by field staff provides indications of changes in water quality. The results obtained can be used to define areas or depths of different water quality that can provide information on aquifer recharge, dewatering or anthropogenic contamination, especially within village environments.

Borehole Monitoring: Some boreholes in the Tabora Region have experienced declining yields and some have failed, after periods of abstraction lasting from some months to a several years. The simple monitoring of borehole yields, which can be undertaken informally by the borehole users, would provide a warning of this problem. Informal monitoring can also be used to identify construction problems such as pump failures.

Hydrogeological Database: The construction of a hydrogeological database, accurately georeferenced, forms an outcome of data collection activities. This will inform future workers, and help to improve drilling success rates. It will also serve to inform the expectations of development workers and communities. A good database can also be the basis for a useful groundwater potential map showing average yields for the different aquifer types, likely depths to groundwater, modes of groundwater occurrence, and water quality information.

\section{Conclusions}

None of the general points made above are new. For example, Grey et al. (1985) demonstrated the importance of hydrogeological expertise in rural water supply work in Malawi more than twenty years ago. These authors showed that costs were lower when a hydrogeologist was involved, especially when he or she is present at the project planning stage. In particular, the hydrogeologist is able to advise on appropriate drilling equipment, borehole siting methods and borehole design. More recently, Robins et al. (2003) have shown the importance of data collection and interpretation to the success of groundwater development projects. Donors, implementers, national governments and others now broadly agree on the need for a more scientific approach to development work, which includes the exploitation of groundwater resources.

The challenge is to make this a reality, since groundwater development in many parts of Africa continues today with very little hydrogeological input. The case studies discussed above show the value of scientific data collection and interpretation, which should ideally be 
explicitly specified in contract documents. Common standards for the collection, storage and sharing of groundwater data need to be agreed on. African groundwater institutions (universities, geological surveys, research organisations, and others) are beginning to cooperate more closely in developing better ways to develop and manage groundwater resources, particularly trans-boundary resources (note for instance the recent International Workshop on Groundwater Protection in Africa, hosted by the University of the Western Cape in Capetown, South Africa, in November 2005). It is necessary to imbed the kind of cooperative, scientific approach demonstrated at this workshop into the discourse of water development in Africa more generally. Most groundwater scientists are now aware of the critical importance of the social, political and institutional context in which water development work is carried out, but it is essential that development managers and fund holders incorporate a scientific assessment of the groundwater resource into water supply strategies.

\section{References}

Arusha Regional Water Master Plan 2000. Part III of the Plan: Methods, Data and Analysis: Volume 14: Groundwater Resources (Hydrogeology), Volume 15 Water Quality and Volume 16: Water Engineering, Final Report, December 2000.

Ashton, P. \& Ramasar, V. 2002. Water and HIV/AIDS: Some strategic considerations in Southern Africa. In: Turton, A. R. \& Henwood, R. (eds.) Hydropolitics in the Developing World: A Southern African Perspective. University of Pretoria, Pretoria.

Black, R. \& Liegeois, J. P. 1993. Cratons, mobile belts, alkaline rocks and continental lithospheric mantle: the Pan-African testimony. Journal of the Geological Society, 150, 89-98.

Boucher, C. 2005. The Rural Water Supply and Sanitation Initiative. (Chanel Boucher, Vice President, Policy, Planning and Research.) African Development Bank Group, New York, United Nations.

Carter, R. C., Tyrrel, S. F \& Howsam, P. 1993. Lessons learned from the UN Water Decade. Journal of the Institution of Water and Environmental Management, 7, 646-650.

CIA, 2006. CIA World Fact Book. World Wide Web Address http://www.cia.gov/cia/publications/factbook/index.html (accessed April 2006). 
Clark, L. 1985. Groundwater abstraction from Basement Complex areas of Africa. Quarterly Journal of Engineering Geology, 8, 25-34.

Cobbing, J. E. \& Davies, J. 2004. Understanding problems of low recharge and low yield in boreholes: an example from Ghana. In: Proceedings of the International Conference on Water Resources of Arid and Semi-arid Regions of Africa (WRASRA), August 3-6 2004, Gaborone, Botswana.

Commission for Africa 2005. Report of the Commission for Africa: March 2005. World Wide Web Address: http://www.commissionforafrica.org/english/report/introduction.htm (accessed April 2006).

Davies, J. \& Cobbing, J. E. 2002. An assessment of the hydrogeology of the Afram Plains, Eastern Region, Ghana. British Geological Survey Technical Report, CR/02/137N.

| Davies, J. \& Ó Dochartaigh, B. É $、$ 2002. Low Permeability Rocks in Sub-Saharan Africa. Groundwater development in the Tabora Region, Tanzania. British Geological Survey Commissioned Report, CR/02/191N.

Davies, J. 2005. Scoping Study to Assess Hydrogeological Support to WaterAid Tanzania. British Geological Survey Technical Report CR/05/174C.

Grey, D. R. C, Chilton, P. J., Smith-Carrington, A. K. \& Wright, E. P. 1985. The expanding role of the hydrogeologist in the provision of village water supplies: an African perspective. Quarterly Journal of Engineering Geology, 18, 13-24.

Harvey, P. \& Reed, B. 2004. Rural Water Supply in Africa. Building Blocks for Handpump Sustainability. WEDC, Loughborough University, UK.

House of Commons Science and Technology Committee 2004. HC 133-1 The Use of Science in UK International Development Policy. Thirteenth Report of Session 2003-04. Volume 1. The Stationery Office, London.

MacDonald, A. M., Davies. J, Calow R. C. \& Chilton, P. J. 2005. Developing Groundwater: a guide for rural water supply. ITDG Publishing, Rugby, UK, Warwickshire, 384pp.

MacDonald. A. M., Kemp, S. J. \& Davies, J. 2005. Transmissivity variations in mudstones. Ground Water, 43, 259-269.

New Partnership for Africa's Development (NEPAD) 2003. Comprehensive Africa Agriculture Development Program (CAADP). NEPAD, Midrand, South Africa. 
Niaz, S. M. 1985. International funding of groundwater development schemes. Quarterly Journal of Engineering Geology, 18, 3-12.

Overseas Development Institute (ODI) 2004. From Plan to Action: Water Supply and Sanitation for the poor in Africa. ODI Briefing Paper July 2004, Overseas Development Institute, London.

Pietersen, K. 2005. Groundwater Crucial to Rural Development. The Water Wheel March/April 2005. Water Research Commission, Pretoria.

Robins, N. S., Davies, J., Farr, J. L. \& Calow, R. C. 2006. The changing role of hydrogeology in semi-arid southern and eastern Africa. Hydrogeology Journal, 14, 1483-1492.

Robins, N. S., Davies, J., Hankin, P. \& Sauer, D. 2003. Groundwater and data - an African experience. Waterlines, 21, 19-21.

SDTF3 2003. Sustainable Development Task Force. Overview of DfID Activities in the Water Sector SDTF3-1003-1. World Wide Web Address: http://www.sustainabledevelopment.gov.uk/government/task-forces/word/10water.doc, (accessed April 2006).

Shackleton, R. M. 1976. Pan-African structures. Philosophical Transactions of the Royal Society, London, 280, 491-497.

Shiklomanov, I. A. 1998. World Water Resources - A New Appraisal and Assessment for the $21^{\text {st }}$ Century. UNESCO, Paris.

Smedley, P. L., Nkotagu, H., Pelig-Ba, K., MacDonald, A. M., Tyler-Whittle, R., Whitehead, E. J. \& Kinniburgh, D. G. 2002. Fluoride in groundwater from high-fluoride areas of Ghana and Tanzania. British Geological Survey Commissioned Report, CR/02/316.

UNDP 2003. Human Development Report 2003. United Nations Development Program (UNDP), New York.

WHO/UNICEF 2007. JMP Report 2006. World Health Organization, UNICEF, Geneva.

World Bank 2005. Global Monitoring Report 2005. Millennium Development Goals: From Consensus to Momentum. The World Bank, Washington.

World Water Forum 2000. The Africa Water Vision for 2025: Equitable and Sustainable Use of Water for Socioeconomic Development. World Water Forum, The Hague, Netherlands. 